\title{
The role of steroids in follicular growth
} Ann E Drummond*

\author{
Address: Prince Henry's Institute of Medical Research, PO Box 5152, Clayton Victoria 3168, Australia \\ Email: Ann E Drummond* - ann.drummond@princehenrys.org \\ * Corresponding author
}

Published: 10 April 2006

Reproductive Biology and Endocrinology2006, 4:16 doi:10.1186/1477-7827-4-16

This article is available from: http://www.rbej.com/content/4/1/16

(c) 2006Drummond; licensee BioMed Central Ltd.

This is an Open Access article distributed under the terms of the Creative Commons Attribution License (http://creativecommons.org/licenses/by/2.0), which permits unrestricted use, distribution, and reproduction in any medium, provided the original work is properly cited.
Received: 04 October 2005

Accepted: 10 April 2006

\begin{abstract}
The steroidogenic pathway within the ovary gives rise to progestins, androgens and oestrogens, all of which act via specific nuclear receptors to regulate reproductive function and maintain fertility. The role of progestins in follicular growth and development is limited, its action confined largely to ovulation, although direct effects on granulosa cell function have been reported. Consistent with these findings, progesterone receptor knockout mice are infertile because they cannot ovulate. Androgens have been shown to promote early follicular growth, but also to impede follicular development by stimulating atresia and apoptosis. The inability of androgens to transduce a signal in mice lacking androgen receptors culminates in reduced fertility. Oestrogens are known to exert effects on granulosa cell growth and differentiation in association with gonadotrophins. Studies with oestrogen receptor knockouts and oestrogen depleted mice have shown us that oestrogen is essential for folliculogenesis beyond the antral stage and is necessary to maintain the female phenotype of ovarian somatic cells. In summary, the action of steroids within the ovary is based on the developmental status of the follicle. In the absence of any single sex steroid, ovarian function and subsequently fertility, are compromised.
\end{abstract}

\section{Introduction}

Follicular development begins during foetal life with the transformation of primordial germ cells into oocytes and their enclosure in structures called follicles. In most mammals, primordial follicles form either before, or in the first few days after birth. Primordial follicles give rise to primary follicles which transform into preantral (secondary follicles) then antral follicles (tertiary follicles) and finally preovulatory, Graafian follicles, in a co-ordinated series of transitions regulated by hormones and local intraovarian factors. The growth and differentiation of follicles from the primordial population is termed folliculogenesis. With the LH surge, Graafian follicles rupture and oocytes are released, leaving the follicular cells to luteinise and form a corpus luteum.
Sex steroids play important roles in the growth and differentiation of reproductive tissues and in the maintenance of fertility. Produced de novo from cholesterol, progestins, androgens and oestrogens are synthesised by the ovary in a sequential manner, with each serving as substrate for the subsequent steroid in the pathway. The two-cell, twogonadotrophin model describes the role of theca and granulosa cells in the production of steroids, highlighting the cooperation between the two cell types, which is necessary for oestrogen production (Figure 1). Given that signal transduction for these hormones usually requires the binding and activation of a ligand-specific receptor, one cannot easily dissociate these components and assign definitive roles. The steroid hormones signal via nuclear receptors to regulate transcriptional events. These receptors form part of a nuclear receptor superfamily, all of 


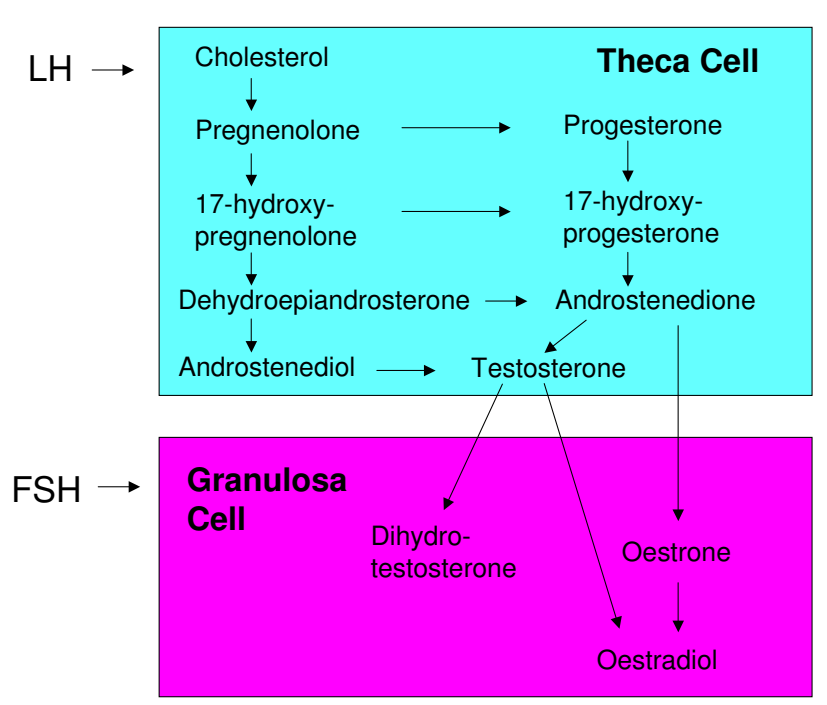

Figure I

Steroid biosynthesis by the ovary. In the theca, under the influence of $\mathrm{LH}$, cholesterol is converted to pregnenolone and metabolised through a series of substrates ending in androgen production. The two-cell, two-gonadotrophin model comes into play with androgens produced by the theca cells transported to the granulosa cells where they are aromatised to oestrogens.

which contain common structural elements $[1,2]$. These include a highly conserved DNA binding domain (DBD), a moderately conserved ligand binding domain (LBD) and 2 transactivation domains, AF1 located in domain A/ $\mathrm{B}$ and AF2 in domain E/F (Figure 2). This review will address the roles that steroid hormones play in follicular development. It will encompass the direct actions of steroids in the ovary that have been reported and include a discussion of relevant models of ovarian dysfunction and nuclear receptor knockout mouse models that lead to disruption of steroid hormone signalling mechanisms and thus an inability of steroids to fulfil their regulatory roles.

\section{Progestins}

In the female reproductive tract, progesterone plays key roles in ovulation, implantation and the maintenance of pregnancy [3]. This review is confined to the roles progesterone plays in regulating granulosa cell function and follicle rupture during ovulation.

Progesterone receptors (PR) comprise two forms PR-A and PR-B $[4,5]$, although they arise from a single gene. These receptors appear to have functionally different roles $[6,7]$ and in vitro data suggests that PR-A is a dominant repressor of PR-B $[8,9]$, with the balance of the two forms determining cellular responsiveness. PR-A and PR-B exhibit different transactivation properties which are cell and promoter specific [5,9-11], indicating actions on separate groups of genes for each receptor, in response to progesterone. They also respond differently to progestin antagonists with PR-B, but not PR-A, becoming a transcriptional activator on binding antiprogestin [12].

PR protein has been localised immunohistochemically to theca of small antral follicles and granulosa cells of preovulatory follicles that had been exposed to LH/hCG, or were undergoing luteinisation, in primate and rabbit ovaries $[13,14]$. PR mRNA has been localised in immature rat ovaries to granulosa cells of large follicles following PMSG/hCG treatment and to large follicles of adult rat ovaries that had been exposed to the LH surge [15]. When the LH surge was blocked, PR mRNA was not induced. Similarly, LH induced PR mRNA expression by cultured porcine granulosa cells [16]. In cultured rat granulosa cells, PR mRNA was induced by LH in a dose and time dependent manner, with the shorter form, PR-A more abundant than the long form, PR-B [17]. The Antiprogestins RU486 and ZK98299, blocked LH-stimulated luteinisation of granulosa cells isolated from preovulatory follicles [17]. PR mRNA was also expressed by primate granulosa cells following an ovulatory dose of hCG, with whole ovaries and corpora lutea also expressing PR [18]. These findings promote the hypothesis that LH-induced PR is essential for ovulation and luteinisation.

Progestins have been shown to enhance the activity of steroidogenic enzymes in gonadotrophin primed granulosa cells [19] and to enhance progesterone production by these cells [20]. Consistent with this finding, RU486 inhibited progesterone production by cultured human granulosa cells by way of decreasing the activity of $3 \beta$ hydroxysteroid dehydrogenase [21]. The direct actions of progesterone on granulosa cells extend to: enhancing the response of cultured rat granulosa cells to FSH by increasing CAMP [22]; inhibiting FSH-stimulated oestradiol production by rat granulosa cells [23-25]; inhibiting the primordial to primary follicle transition in newborn rats [26]; inhibiting insulin-dependent granulosa cell mitosis $[27,28]$ and inhibiting apoptosis by large granulosa cells in culture (granulosa cells isolated from immature rat ovaries were separated based on their size eg small or large), which do not express PR [29]. It was puzzling that RU486, a PR antagonist, inhibited the anti-apoptotic action of progesterone, given the absence of receptors from granulosa cell. Consequently it has been proposed that some of the actions of progesterone, notably the inhibition of apoptosis and insulin-dependent mitosis, are mediated by non-genomic mechanisms [30,31]. The identification of a progesterone binding protein $\left(60 \mathrm{kDa} \mathrm{P}_{4} \mathrm{BP}\right)$ within ovarian and granulosa cell lysates [32] and progestin membrane receptors in rat corpora lutea [33], a tissue that 
Nuclear Hormone Receptor Structure

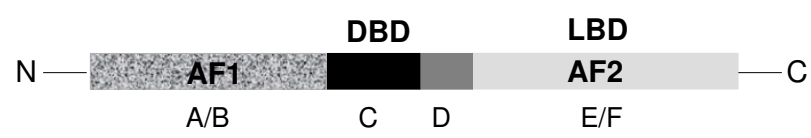

Figure 2

The structure of nuclear hormone receptors. These receptors are composed of 5 structure-function domains labelled A-F (Mangelsdorf et al., 1995) The N-terminal region contains domains $A / B$, the DNA binding domain (DBD) contains domain $C$, the hinge region contains domain $D$ and the ligand binding domain (LBD) at the C-terminal end contains

domains E/F. Transactivation domains AFI and AF2 are found in the $\mathrm{N}$-terminal region and the LBD, respectively (White \& Parker 1998).

does not express detectable levels of nuclear progesterone receptors, may facilitate the actions of progesterone.

At ovulation, the Graafian follicle ruptures releasing the ovum. Thereafter, the follicle undergoes remodelling to form a corpus luteum, which secretes progesterone. The ovulatory process is progesterone dependent. Inhibitors of progesterone synthesis, notably aminoglutethimide, epostane and RU486, have been shown to block LHinduced ovulation in vivo and in vitro in rats and mice [3437]. There is also the suggestion that progesterone is involved in stimulating ovulation in the human [38]. Firstly, it has been shown that the rise in progesterone precedes that of gonadotrophins $[39,40]$. Secondly, in luteinised unruptured follicle (LUF) syndrome, the preovulatory rise in progesterone observed in normal women is delayed and follicles fail to rupture although they undergo luteinisation [41]. Thirdly, the administration of RU486 blocked the LH surge and ovulation [42]. In specific terms, progesterone has been shown to enhance the production of proteolytic enzymes important for the rupture of follicles at ovulation [43], either directly, or by enhancing endometrial relaxin production [44], which is thought to stimulate the release of proteases by granulosa cells [45]. The expression of two metalloproteinases ADAMTS-1 and cathepsin- $\mathrm{L}$, thought to be required for ovulation, by granulosa cells of anovulatory follicles of PR null mice, is inhibited indicating a dependence on PR for normal expression [46].

The importance of PR in female reproduction is underscored by the infertility of PR null mice [47]. Despite histologically normal ovaries, these mice fail to ovulate even after exogenous stimulation with gonadotrophins, as indicated by the presence of unruptured preovulatory follicles in the ovary and an absence of oocytes in the oviduct and uterine horns [47]. The granulosa cells of these preo- vulatory follicles luteinise, suggesting that $\mathrm{PR}$ is not required for corpus luteum formation [46]. However, this observation conflicts with the credible report of Natraj and Richards (1993) [17], that progesterone acting at least in part via PR, is required for luteinisation (see earlier paragraph). The development of PR-A and PR-B knockouts reveals that PR-A is necessary for ovulation whereas PR-B is not $[48,49]$. Consequently, PR-A knockouts were infertile, the result of a failure to ovulate, whereas PR-B knockouts were ovulatory and produced viable offspring. These studies further highlight the capacity of PR-A and PR-B to mediate different actions of progesterone [50].

\section{Androgens}

Androgens, primarily androstenedione and testosterone, are produced by theca cells in response to LH (Figure 1). Androgens act via receptors (AR) localised to granulosa cells, stromal cells [51-53], human theca cells [54] and more recently, to rat, pig and mouse oocytes [55-57]. Androgens predominantly target granulosa cells where they initiate scenarios depending on the developmental status of the follicle and species. AR expression is highest in granulosa cells of: preantral and antral follicles of primate ovaries [58,59]; small preantral and early antral follicles of rat ovaries $[53,60]$; small antral follicles of porcine ovaries [61]; preantral to early antral follicles of bovine ovaries [62] and secondary and dominant follicles of human ovaries [54]. The expression of AR may be influenced by oocyte secreted factors. Tetsuka and colleagues [53] reported that a gradient of AR immunostaining existed in large follicles of the rat ovary, with cumulus cells and antral granulosa cells strongly expressing AR protein and peripheral layers expressing less [53].

In the early stages of folliculogenesis, androgens appear to promote follicular growth. Administration of testosterone to pregnant ewes and thus prenatal treatment of fetuses with androgen, led to decreased numbers of primordial follicles and enhanced numbers of follicles at other stages of development, indicating that testosterone was enhancing follicular recruitment [63]. Since testosterone can be aromatised to oestrogen at this stage of development, it is difficult to determine whether this is a direct effect of testosterone or an indirect effect, by way of providing substrate for aromatisation. In female rhesus monkeys prenatally androgenised with testosterone, large polyfollicular ovaries that resemble polycystic ovaries found in women with polycystic ovary syndrome (PCOS) develop [64-66]. The diameter of mouse preantral follicles cultured in vitro for four days with either testosterone, dihydrotestosterone, androstenedione, dehydroepiandrosterone or dehydroepiandrosterone sulfate, expanded and the granulosa cells labelled strongly with bromodeoxyuridine, an indicator of cellular proliferation [67]. An AR antagonist, but not an aromatase inhib- 
itor, inhibited the growth response, indicating that oestrogen converted from the androgens in culture, was not responsible for follicle growth. A direct stimulatory effect of androgens on mouse antral follicle growth in vitro, has also been demonstrated [68]. More recently, dihydrotestosterone has been shown to enhance porcine granulosa cell proliferation, by potentiating the effects of factors, most likely GDF9, secreted by denuded oocytes in vitro [69]. In primates treated short term with androgens, increased numbers of preantral and small antral follicles were present in the ovary and the theca had undergone hypertrophy [70]. In pigs, numbers of preovulatory follicles and corpora lutea were increased when treated with testosterone or dihydrotestosterone during the follicular phase $[56,71,72]$. During late preovulatory development, AR decline in most mammals, the exception being humans and androgens are metabolised as opposed to exerting direct effects on folliculogenesis [73].

Apart from effects on growth, androgens have been shown to enhance the follicle stimulating hormone (FSH)-mediated differentiation of granulosa cells, as indicated by an increase in progesterone and oestradiol production [74$76]$ and to play roles in oocyte maturation. In vitro, testosterone induced the maturation of mouse oocytes arrested at meiosis, via a transcription independent mechanism [57]. The addition of flutamide, an $\mathrm{AR}$ antagonist, blocked the maturation. Stimulatory effects of dihydrotestosterone on FSH receptor mRNA expression by preovulatory follicles of gilts [56] and testosterone on FSH receptor mRNA expression by primate primary follicles [77], have also been reported. These studies suggest that androgens can facilitate the response of follicles to FSH. Components of the ovarian IGF-I signalling system have been shown to be regulated by androgens. IGF-I and IGF-I receptor mRNAs have been shown to be enhanced by both testosterone and dihydrotestosterone in primates $[78,79]$. The broad localisation of the IGF-I and IGF-I receptor mRNA's (granulosa cells, theca, oocytes and interstitial cells) suggests wide ranging roles for androgen in ovarian function.

Androgens have also been shown to impede follicular development, enhancing follicular atresia in immature rats primed with PMSG $[80,81]$ and in estrogen-treated hypophysectomised immature rats [82]. A single injection of dihydrotestosterone to cycling mice reduced the number of large follicles by fifty percent [83] and left the mice subfertile. Androgens are reported to inhibit FSHstimulated LH receptor expression by granulosa cells $[84,85]$ and to modulate granulosa cell apoptosis, enhancing the process in the rat [86], but demonstrating a negative correlation with androgen receptor suggestive of reduced effects on granulosa cell apoptosis, in the rhesus monkey [58].
In humans, hyperandrogenism is a classic symptom of PCOS [Reviews: [87-89]]. Abnormal steroidogenesis by the ovary is responsible for the androgen excess, which is thought to impact on the level and distribution of adiposity in PCOS patients and predispose them to insulin resistance and anovulation [90]. It is thought that the theca cells of PCOS ovaries are not responsive to downregulation by gonadotrophins allowing for unchecked androgen production [91]. The hypertrophy of theca, which occurs in PCOS ovaries, exacerbates the problem. Evidence for the role of androgens in anovulation comes from PCOS patients treated with the antiandrogen, flutamide. After six months treatment, ovulation was restored [92]. In addition, when hormone therapy for ovulation induction (clomiphene and follicle stimulating hormone regimen) was supplemented with cyproterone acetate, an antiandrogen, ovulation and pregnancy rates were highest [93]. These reports however, are counterbalanced by a study in which the antiandrogen, nilutamide, did not stimulate ovulation in anovulatory PCOS patients [94]. The cystic nature of PCOS ovaries has been replicated in the immature rat with a view to determining why anovulation occurs. Collagen degradation of the follicular wall at ovulation is essential for oocyte release. The role of matrix metalloproteinases (MMP), which degrade collagen and lysyl oxidase (LOX), a cross-linker of collagen and elastin normally involved in collagen repair or reconstruction, were investigated in this dehydroepiandrosteroneinduced rat model of PCOS [95]. The study established that in response to androgen, MMP2 activity was significantly reduced whereas LOX activity was significantly enhanced, indicating that collagen breakdown and follicle rupture could potentially be inhibited, thus explaining the cystogenesis that occurs in PCOS. Clearly, the mechanisms that lead to anovulation in a sub group of PCOS patients are complex and not fully understood. Recent criteria defining PCOS indicate that the ovary should contain 12 follicles or more, $2-9 \mathrm{~mm}$ in diameter, or ovarian volume greater than $10 \mathrm{~cm}^{3}[96]$. The premature development of follicles in PCOS ovaries is thought to be due to the elevated levels of androgen. Support for this hypothesis comes from the primate study discussed earlier [70]. Follicle development is either arrested as in anovulatory PCOS, the follicles remaining healthy and steroidogenic [97], or tending toward atresia as in ovulatory PCOS [98]. Elevated levels of androgens are thought to activate cell death pathways in preantral granulosa cells [87]. The low levels of aromatase in atretic follicles foster the conversion of androgens to dihydrotestosterone rather than to oestrogen, perpetuating the androgen excess $[99,100]$. Recent studies by Maciel and colleagues [101] propose an alternative theory to androgen stimulated follicular growth; that follicular growth is actually slowed in PCOS ovaries causing primary follicles to 'stockpile' [101]. Significantly more primary, secondary and Graafian follicles were 
found in PCOS ovaries compared with normal ovaries, although the greatest increase in follicle numbers was observed in what was termed 'classic' primary follicles, that is those follicles in which the oocyte is surrounded by a single layer of fully cuboidal granulosa cells. No changes in primordial follicle numbers or the numbers of atretic follicles were seen in PCOS ovaries [101], adding weight to the 'stockpiling' theory.

Despite the apparent roles for androgens in the ovary, studies on the testicular feminised mouse (Tfm), which lack functional androgen receptors, indicate that AR are not essential for fertility [102]. The reproductive lifespan of these mice however, was reduced due to accelerated aging of the ovary and they were subfertile [102]. The development of an androgen receptor conditional knockout has furthered studies on androgen action in the ovary. Female AR knockout mice have longer oestrous cycles and reduced fertility, evident in fewer litters and reduced numbers of pups. Their ovaries contain normal numbers of follicles, although large antral follicles appeared to have fewer granulosa cells and there were reduced numbers of corpora lutea [103]. These observations are consistent with studies in PMSG treated immature rats, where androgen reduced ovulation rate by decreasing the number of granulosa cells per follicle [81]. Superovulation induction in these androgen receptor knockouts, led to the formation of abnormal cumulus-oocyte complexes [103].

One of the most important roles played by androgens in the ovary is in the synthesis of oestrogen. Androgens serve as substrates of P450 aromatase, which mediates the conversion to oestrogens [[104], Reviews [73,105]].

\section{Oestrogens}

The capacity of follicles to make oestrogen is first apparent in the late preantral stage when they possess all the components of the 'two cell, two gonadotrophins' model. Although aromatase activity is present in small antral follicles, oestrogen production at this stage of development is limited by an inability to produce androgen substrate for aromatization to oestrogen [106]. Growth beyond the small antral stage is therefore characterised by increased aromatase activity and androgen synthesis, which culminates in follicular oestrogen production. The preovulatory follicle has the highest intrafollicular levels of estradiol, primarily due to the size of its granulosa cell population and its capacity for androgen aromatisation $[107,108]$.

Oestrogens signal via receptors (ER) of which there are two forms, ER $\alpha$ and ER $\beta$ [109-113], with ER $\beta$ being the predominant form in the ovary $[114,115]$. A number of variant forms of ER $\beta$ have been identified in the human [Review: [116]]. ER $\beta$ mRNAs lacking exon 5 and/or 6 [117] and ER $\beta 2 / c x, E R \beta 2, E R \beta 4$ and ER $\beta 5[118,119]$
mRNAs are all expressed by the ovary. The functional significance of these forms however, is unclear. During postnatal development, the mRNA expression of ER $\beta$ increases in synergy with the proliferation of granulosa cells in the rat ovary. ER $\alpha$ mRNA levels in contrast, remain stable after its initial induction [115], indicative of a more widespread expression profile as highlighted by protein localisation studies in the ovary [120-122]. Recent studies using isotype-selective, estrogen receptor agonists have assessed the individual roles that ER $\alpha$ and ER $\beta$ play in female reproduction [123]. Distinct roles for each receptor were identified: ER $\alpha$ inhibited ovulation, most likely via an effect on the hypothalamo-pituitary axis and uterine growth; while ER $\beta$ stimulated follicular growth, decreased atresia, induced the expression of specific genes and enhanced the number of oocytes released following ovulation induction.

Oestrogen has acknowledged local intrafollicular actions [[124,125], Reviews: [126-128]]. Administration of oestrogen to hypophysectomised rats stimulates the proliferation of granulosa cells in small preantral follicles and reduces atresia $[129,130]$. Subsequent administration of FSH to these oestrogen-primed hypophysectomised rats results in increased follicular growth and differentiation and antrum formation [131]. It is interesting to note that although oestrogen alone is a potent mitogen on rodent granulosa cells in vivo, it is devoid of mitogenic activity in vitro. This indicates that the in vitro culture systems are incapable of maintaining the mitogenic responsiveness of granulosa cells to oestrogen and/or other intrafollicular growth factors, some of thecal origin, may be involved in the mitogenic actions of oestrogen [132]. Studies of Bley and colleagues (1997) [133] indicate that a combination of oestrogen and FSH or androgen, perhaps aromatised in vitro to oestrogen and $\mathrm{FSH}$, can stimulate granulosa cell proliferation in vitro and that this effect is further amplified by insulin or IGF-1 [133]. It is not clear what genes oestrogen induces in granulosa cells, but cyclin D2 [134], inhibin $\alpha$ and inhibin $\beta B$ [135] are likely candidates.

Oestrogen is also responsible for facilitating the differentiation of granulosa cells including the induction of receptor systems for FSH, LH and prolactin and it can influence post-receptor mechanisms. In conjunction with LH and $\mathrm{FSH}, \mathrm{E}_{2}$ stimulates cAMP accumulation [136] and increases the number of CAMP binding sites in granulosa cells [137]. There is now evidence that FSH can activate the IGF-1/phosphatidylinositol 3-kinase (PI3K)/phosphatidylinositol-dependent kinase 1 (PDK1) pathway in granulosa cells with serum and glucocorticoid-induced kinase (Sgk) and protein kinase B (PKB) or Akt, kinases being phosphorylated [138]. These effects can be mimicked by forskolin, cAMP and IGF-1 and can conceivably be enhanced by oestrogen. Targets for PKB and Sgk 
include members of the forkhead (FOX) family of transcription factors of which forkhead homologue of rhabdomysarcoma (FKHR) is a member. FKHR is expressed by granulosa cells, its expression enhanced by FSH and oestrogen [138]. The role of FKHR in granulosa cells has yet to be elucidated but it may be linked with proliferation since cells expressing FKHR also expressed cyclin D2 and showed enhanced staining for proliferating cell nuclear antigen (PCNA) [139,140].

\section{Oestrogen Receptor Knockout mice}

In recent years, oestrogen receptor knockout mice have been generated in an effort to define the points of oestrogen action in the ovary. The ER $\alpha$ knockout (ERKO) and ER $\beta$ knockout (BERKO) mice however, are not oestrogenfree given their capacity to transduce a signal via the alternative oestrogen receptor subtype. The female ERKOs are acyclic, infertile and possess hyperemic ovaries devoid of corpora lutea. Folliculogenesis is arrested at the antral stage with large follicles becoming cystic and haemorrhagic $[141,142]$. Prolonged administration of a GnRH antagonist to ERKO mice prevented formation of the haemorrhagic cysts [143], indicating that the ovarian phenotype manifests as a consequence of elevated LH levels $[144,145]$. Gonadotrophin-treated prepubescent ERKO mice ovulate, although they released fewer oocytes compared to their wildtype counterparts [146]. Thus, it would appear that folliculogenesis, ovulation and corpora lutea formation can occur in the absence of ER $\alpha$, albeit suboptimally.

The female BERKOs [147-149] have small ovaries, partially arrested follicular development associated with increased numbers of primordial follicles, but significantly fewer numbers of primary and large antral follicles and corpora lutea. Increased atresia of large follicles is evident. In culture, BERKO follicle growth was retarded and they produced significantly less oestrogen and expressed less aromatase than wildtype follicles [149]. Compromised fertility was evident in reduced numbers of offspring/litter, consistent with the reduced numbers of corpora lutea [147]. Following ovulation induction, fewer oocytes were released from BERKO ovaries relative to their wildtype counterparts. This is likely to be due to reduced Ptgs2 expression, a gene necessary for ovulation, by BERKO follicles after gonadotrophin stimulation $[149,150]$. Interestingly, gonadotrophin levels in these mice are normal. These studies indicate that ER $\beta$ plays an essential role in gonadotrophin-induced granulosa cell differentiation. In its absence, follicle maturation and the ovulatory process are impaired. Androgen receptor (AR) analyses of BERKO mice ovaries revealed an increased expression of AR in late antral and atretic follicles [148], a time in wildtype animals when AR expression is low. Androgens are known to enhance atresia [80-82] and thus the overexpression of AR by the ovaries of BERKO mice most likely accounts for the increased atresia and premature exhaustion of follicles observed in these mice. Treatment with the antiandrogen, flutamide reversed the BERKO ovarian phenotype, the ovaries containing healthy late antral follicles and increased numbers of corpora lutea [148]. A role for androgens in the manifestation of the BERKO phenotype and thus in ovarian folliculogenesis is clearly indicated.

The generation of double ER knockout ( $\alpha \beta E R K O)$ mice by two laboratories $[151,152]$ and reports of their ovarian phenotype, indicate that these mice are distinct from the individual ER knockouts. These ovaries exhibit follicular trans/re-differentiation with tubular-like structures containing Sertoli-like cells. Where oocytes were present these were seen to be degenerating, raising the possibility that factors produced by the oocyte may be involved in the transformation process. The capacity to be effected by oestrogens or a lack there of, is asserted by the presence of ER $\alpha$ mRNA in mouse and human oocytes [153-155]. The phenotype is expressed in the presence of elevated LH levels, similar to that of the ERKO mouse. Thus it appears that both ERs have roles to play in the maintenance of fertility, although ER $\beta$ appears essential for follicle development and maturation.

\section{Oestrogen depletion - the ArKO mouse}

An alternative model to ER depletion is to remove oestrogen itself from the ovary. Targeted deletion of most of exon 9 of the Cyp 19 (aromatase) gene has given rise to a mouse which lacks functional aromatase and thus an inability to produce oestrogen [156]. Female ArKO mice have undetectable levels of aromatase and oestrogens but exhibit high levels of testosterone, FSH and LH in serum. These reproductive hormones have been implicated as playing crucial roles in various aspects of folliculogenesis [Reviews: [157,158]]. The ArKO model has allowed us to define how far follicles can grow in the total absence of oestrogen $[156,159,160]$. We established that follicle development was arrested at the antral stage rendering these mice infertile due to an inability to ovulate. The antral follicles that were present appeared morphologically atretic or prematurely luteinized, as evidenced by the presence of pyknotic nuclei or cytoplasmic lipid droplets, respectively. The phenotype exacerbates with age, the ovarian interstitium becoming increasingly diffuse and containing increasing numbers of morphologically abnormal follicles and haemorraghic cysts [160]. Secondary and antral follicles become less common in the ovary and eventually the number of primary follicles also decreases $[159,161]$. Recent studies quantitating the primordial follicle pool, indicate that there are reduced numbers of primordial follicles in ArKO ovaries and that their oocytes are enlarged [162]. 
The phenotype of the somatic cells in the ArKO ovary, has been investigated both ultrastructurally and immunohistochemically $[160,161]$ and gene expression studies have been performed [163]. Detailed light microscopy identified the abnormal follicles as seminiferous tubule-like structures filled with Sertoli-like somatic cells, apparently arising from the trans/re-differentiation of granulosa cells. These Sertoli-like cells possess adult-type Sertoli cells characteristics, including a tall irregular columnar shape and lateral cylindrical-like processes; basally located nuclei; prominent tripartite nucleoli and a homogeneous nuclear chromatin distribution, specialised desmosome-like adherens junctions and Sertoli-cell specific, ectoplasmic specialisations between cells [160]. Cells morphologically resembling testicular Leydig cells were present within the interstitial regions of ArKO ovaries [160,164]. These Leydig cell-like cells contain an abundance of smooth endoplasmic reticulum, often present in whorl-like formations and the nucleus accommodated an annular nucleolus, all characteristics of murine Leydig cells. It is unclear at this stage if these cells are functional ie., whether they possess steroidogenic enzymes. The expression of the male type genes, Sox 9 and Mullerian inhibiting substance (MIS) were increased in ArKO mice ovaries [163], indicating that oestrogen is required for maintenance of the female phenotype of ovarian somatic cells. Thus, in the absence of oestrogen, the ovaries undergo sex reversal and testicular type cells appear, indicating that gonadal cells retain a degree of plasticity. Oestrogen replacement partially restored the ovarian phenotype, eliminating male-like cells from the ovary and allowing limited ovulation in some ArKO mice [162,163].

These data confirm and extend observations in $\alpha \beta E R K O$ mice in which Sertoli-like cells with similar properties were observed in the ovaries $[151,152]$. These compound ER knockouts are not oestrogen-free and it is possible that there remains an influence of oestrogen via some as-yet unidentified ER, particularly since an ER $\gamma$ form has been identified in fish [165]. A non-genomic action of oestrogen can also not be ruled out. The presence of Sertoli-like and Leydig-like cells in the ovaries of ArKO mice on a phytoestrogen-free diet, indicates that these cells only develop in the complete absence of oestrogen. Thus oestrogen is required for normal folliculogenesis, from the antral stage on. The development of antral and preovulatory follicles is prerequisite for ovulation and corpus luteum formation and for the maintenance of fertility.

The role of the oocyte in the trans/redifferentiation of granulosa cells in these animal models has been unclear. Recent studies in irradiated rats [166] have addressed this question. Oocytes in non-growing follicles were selectively destroyed by gamma irradiation. The follicular cells that remained differentiated into Sertoli-like cells and expressed morphological characteristics of Sertoli cells, although some traits of follicular cells, such as the expression of FOXL2 protein remained. These cells did not express oestrogen receptors, so despite normal levels of oestrogen, a signal could not be transduced by them. Despite similarities with the sex reversed cells reported in ArKO or ER double knockout mouse ovaries, these transdifferentiated follicular cells did not express Sox 9. They also established a role for FSH in the development of these transdifferentiated oocyte depleted follicles. While FSH levels are elevated in ArKO mice [159], a role for FSH in the development of sex-reversed cells has yet to be shown. Studies to elucidate the oestrogen-mediated mechanisms that operate between the oocyte and the somatic cells, to maintain and promote the folliculargranulosa cell phenotype are only just starting to be undertaken. Otsuka and colleagues [167] recently reported that oocytes mediate oestrogen's enhancement of FSH action on P450 aromatase, FSH and LH receptor and inhibin/activin subunit mRNA expression and cAMP production by granulosa cells in vitro [167].

\section{Conclusion}

Steroid hormones, via ligand-specific receptors, play important regulatory roles in the ovary. The impact of these hormones on ovarian function is determined by ligand availability, receptor expression and the repression or induction of relevant regulatory genes. Ultimately, it is the needs of individual follicle populations, which determine the roles that steroids play. From the data presented in this review, it is clear that each steroid plays roles of consequence for fertility. In their absence, or in cases of excess, ovarian function and subsequently fertility, is compromised.

\section{Acknowledgements}

The author wishes to thank Prof Jock Findlay for his critical reading of the manuscript and acknowledge the financial support of the NH\&MRC (Regkey \#241000).

\section{References}

I. Mangesldorf DJ, Thummel C, Beato M, Herrlich P, Schutz G, Umesono K, Blumberg B, Kastner P, Mark M, Chambon P, Evans R: The nuclear receptor superfamily: the second decade. Cell I995, 83:835-839.

2. White R, Parker MG: Molecular mechanisms of steroid hormone action. Endo Related Canc 1998, 5:1-14.

3. Graham JD, Clarke CL: Physiological action of progesterone in target tissues. Endocrine Rev 1997, I 8:502-519.

4. Spelsberg TC, Steggles AW, Chytil F, O'Malley BW: Progesteronebinding components of chick oviduct. Exchange of progesterone-binding capacity from target to nontarget tissue chromatins. J Biol Chem 1972, 247: I368-I374.

5. Kastner P, Krust A, Turcotte B, Stropp U, Tora L, Gronemeyer H, Chambon P: Two distinct oestrogen-regulated promoters generate transcripts encoding the two functionally different human progesterone forms $A$ and B. EMBO J 1990, 9:1603-1614

6. Conneely OM, Mulac-Jericevic B, Lydon JP: Progesterone-dependent regulation of female reproductive activity by two distinct progesterone receptor isoforms. Steroids 2003, 68:771-778. 
7. Conneely OM, Mulac-Jericevic B, DeMayo F, Lydon JP, O'Malley BW: Reproductive functions of progesterone receptors. Rec Prog Horm Res 2002, 57:339-355.

8. Tung L, Mohamed MK, Hoeffler JP, Takimoto GS, Horwitz KB: Antagonist-occupied human progesterone B-receptors activate transcription without binding to progesterone response elements and are dominantly inhibited by A-receptors. Mol Endocrinol 1993, 7:1256-1265.

9. Vegeto E, Shabaz MM, Wen DX, Goldman ME, O'Malley BW, McDonnell DP: Human progesterone receptor $A$ form is a cell- and promoter-specific repressor of human progesterone receptor B function. Mol Endocrinol 1993, 7:1244- 255.

10. Tora L, Gronemeyer H, Turcotte B, Gaub MP, Chambon P: The Nterminal region of the chicken progesterone receptor specifies target gene activation. Nature 1988, 333:|85-I88.

II. Meyer ME, Quirin-Stricker C, Lerouge T, Bocquel MT, Gronemeyer $\mathrm{H}$ : A limiting factor mediates the differential activation of promoters by the human progesterone receptor isoforms. J Biol Chem 1992, 267:10882-10887.

12. Sartorius CA, Groshong SD, Miller LA, Powell RL, Tung L, Takimoto GS, Horwitz KB: New T47D breast cancer cell lines for the independent study of progesterone B- and A-receptors: only antiprogestin-occupied B-receptors are switched to transcriptional agonists by cAMP. Cancer Res 1994, 54:3868-3877.

13. Hild-Petito S, Stouffer RL, Brenner RM: Immunocytochemical localisation of oestradiol and progesterone receptors in the monkey ovary throughout the menstrual cycle. Endocrinology 1988, 1 23:2896-2905.

14. Iwai T, Fuji S, Nanbu Y, Nonogaki H, Konishi I, Mori T, Okamura H: Effect of human chorionic gonadotrophin on the expression of progesterone receptors and oestrogen receptors in rabbit ovarian granulosa cells and the uterus. Endocrinology 1991, 129: | 840-1848.

15. Park OK, Mayo KE: Transient expression of progesterone receptor messenger RNA in ovarian granulosa cells after the preovulatory luteinizing hormone surge. Mol Endocrinol I991, 5:967-978.

16. Iwai M, Yasuda K, Fukuoka M, Iwai T, Takakura K, Taii S, Nakanishi S, Mori T: Luteinising hormone induces progesterone receptor gene expression in cultured porcine granulosa cells. Endocrinology 1991, 129:1621-1627.

17. Natraj U, Richards JS: Hormonal regulation, localisation and functional activity of the progesterone receptor in granulosa cells of rat preovulatory follicles. Endocrinology 1993, 133:761-769.

18. Chandrasekher YA, Melner MH, Nagalla SR, Stouffer RL: Progesterone receptor but not oestradiol receptor messenger ribonucleic acid is expressed in luteinizing granulosa cells and the corpus luteum in rhesus monkeys. Endocrinology 1994, | 35:307-3 |4.

19. Ruiz de Galarreta CM, Fanjul LF, Hsueh AJ: Progestin regulation of progesterone biosynthetic enzymes in cultured rat granulosa cells. Steroids 1985, 46:987-1002.

20. Fanjul LF, de Galarreta R, Hsueh AJW: Progestin augmentation of gonadatrophin-stimulated progesterone production by by cultured rat granulosa cells. Endocrinology | 983, II 2:405-407.

21. DiMattina M, Albertson B, Seyler DE, Loriaux DL, Falk RJ: Effect of the antiprogestin RU486 on progesterone production by cultured human granulosa cells: inhibition of the ovarian 3Bhydroxysteroid dehydrogenase. Contraception 1986, 34: 199-206.

22. Goff AK, Leung PCK, Armstrong DT: Stimulatory action of follicle-stimulating hormone and androgen on the responsiveness of rat granulosa cells to gonadotrophin in vitro. Endocrinology 1979, 104: I I24-I I 29.

23. Schreiber JR, Nakamura K, Erickson GF: Progestins inhibit FSHstimulated steroidogenesis in cultured rat granulosa cells. Mol Cell Endocrinol 1980, 19:165-173.

24. Schreiber JR, Nakamura K, Erickson GF: Progestins inhibit FSHstimulated granulosa oestrogen production at a post-cAMP site. Mol Cell Endocrinol 1981, 21:161-170.

25. Fortune JE, Vincent SE: Progesterone inhibits the induction of aromatase activity in rat granulosa cells in vitro. Biol Reprod 1983, 28:1078-1089.

26. Kezele P, Skinner MK: Regulation of ovarian primordial follicle assembly and development by oestrogen and progesterone: endocrine model of follicle assembly. Endocrinology 2003, I 44:3329-3337.

27. Luciano AM, Peluso JJ: Effect of in vivo gonadotrophin treatment on the ability of progesterone, oestrogen and cyclic adenosine 5'-monophosphate to inhibit insulin-dependent granulosa cell mitosis in vitro. Biol Reprod 1995, 53:664-669.

28. Peluso JJ, Luciano AM, Pappalardo A, White BW: Cellular and molecular mechanisms that mediate insulin-dependent rat granulosa mitosis. Biol Reprod 1995, 52: I 24-130.

29. Peluso JJ, Pappalardo A: Progesterone and cell-cell adhesion interact to regulate rat granulosa cell apoptosis. Biochem Cell Biol 1994, 72:547-55I.

30. Peluso Jj: Progesterone as a regulator of granulosa cell viability. I Steroid Biochem Molec Biol 2003:167-173.

31. Bramley T: Non-genomic progesterone receptors in the mammalian ovary: some unresolved issues. Reproduction 2003, I 25:3-15.

32. Peluso JJ, Pappalardo A: Progesterone mediates its antimitogenic and anti-apoptotic actions in rat granulosa cells through a progesterone binding protein with GABAA receptor like features. Biol Reprod 1998, 58: I I I- I I37.

33. Cai Z, Stocco C: Expression and regulation of progestin membrane receptors in the rat corpus luteum. Endocrinology 2005 in press.

34. Lipner H, Greep RO: Inhibition of steroidogenesis at various sites in the biosynthetic pathway in relation to induced ovulation. Endocrinology 1971, 88:602-607.

35. Loutradis D, Bletsa R, Aravantinos L, Kalliandis K, Michalas S, Psychoyos A: Preovulatory effects of the progesterone antagonist mifepristone (RU486) in mice. Hum Reprod 1991, 6:1238-1240

36. Tanaka N, Espey LL, Stacy S, Okamura H: Epostane and indomethacin actions on ovarian kallikrein and plasminogen activator activities during ovulation in the gonadotrophin-primed immature rat. Biol Reprod 1992, 46:665-670.

37. Uilenbroek JThJ, Sanchez-Criado JE, Karels B: Decreased luteinizing hormone-stimulated progesterone secretion by preovulatory follicles from cyclic rats treated with the progesterone antagonist RU486. Biol Reprod 1992, 47:368-373.

38. Zalanyi S: Progesterone and ovulation. Eur J Obstet Gynecol Reprod Biol 2001, 98:152-I59.

39. Aedo A-R, Landgren B-M, Diczfalusay E: Studies on ovarian and adrenal steroids at different phases of the menstrual cycle. Dynamic changes during the ovulatory period. Contraception 1981, 23:107-124.

40. Liu JH, Yen SSC: Induction of midcycle gonadotrophin surge by ovarian steroids in women: a critical evaluation. J Clin Endocrinol Metab 1983, 57:797-80|.

4I. Schenken RS, Werlin LB, Williams RF, Prihoda TJ, Hodgen GD: Histologic and hormonal documentation of the luteinised unruptured follicle syndrome. Am J Obstet Gynaecol 1986, 154:839-847.

42. Zalanyi S: Antiprogesterone blocks LH peak and ovulation. In Proceedings of the First European Congress of Endocrinology Copenhagen, Denmark; 1987. Abstract no. 184

43. Iwamasa J, Shibata S, Tanaka N, Matsuura K Okamura H: The relationship between ovarian progesterone and proteolytic enzyme activity during ovulation in the gonadotrophintreated immature rat. Biol Reprod 1992, 46:309-313.

44. Yki-jarvinen $H$, Wahlstom $T$, Seppala M: Human endometrium contains relaxin that is progesterone-dependent. Acta Obstet Gynaecol Scand 1985, 64:663-665.

45. Too CK, Bryant-Greenwood GD, Greenwood FC: Relaxin increases the release of plasminogen activator, collagenase and proteoglycanase from rat granulosa cells in vitro. Endocrinology 1984, I I 5: 1043-1050.

46. Robker RL, Russell DL, Espey LL, Lydon JP, O'Malley BW, Richards JS: Progesterone-regulated genes in the ovulation process: ADAMTS-I and cathepsin $L$ proteases. Proc Natl Acad Sci (USA) 2000, 97:4689-4694.

47. Lydon JP, DeMayo FJ, Funk CR, Mani SK, Hughes AR, Montgomery CA Jr, Shyamala G, Conneely OM, O'Malley BW: Mice lacking progesterone receptor exhibit pleiotropic reproductive abnormalities. Genes Dev 1995, 9:2266-2278.

48. Mulac-Jericevic B, Mullinax RA, DeMayo FJ, Lydon JP, Conneely OM: Subgroup of reproductive functions of progesterone medi- 
ated by progesterone receptor-B isoform. Science 2000 , 289: $1751-1754$

49. Mulac-Jericevic B, Lydon JP, DeMayo FJ, Conneely OM: Defective mammary gland morphogenesis in mice lacking the progesterone receptor B isoform. Proc Natl Acad Sci (USA) 2003, 1 00:9744-9749.

50. Mulac-Jericevic B, Conneely OM: Reproductive tissue selective actions of progesterone receptors. Reproduction 2004, 128:139-146.

5I. Schreiber JR, Ross GT: Further characterisation of a rat ovarian testosterone receptor with evidence for nuclear translocation. Endocrinology 1976, 99:590-596.

52. Hirai M, Hirata S, Osada T, Hagihara K, Kato J: Androgen receptor mRNA in the rat ovary and uterus. J Steroid Biochem Mol Biol 1994, 49: I-7.

53. Tetsuka M, Whitelaw PF, Bremner WJ, Millar MR, Smyth CD, Hillier $S G$ : Developmental regulation of androgen receptor in rat ovary. J Endocrinol 1995, 145:535-543.

54. Horie K, Takakura K, Fujiwara H, Suginami H, Liao S, Mori T: Immunohistochemical localisation of androgen receptor in the human ovary throughout the menstrual cycle in relation to oestrogen and progesterone receptor expression. Hum Reprod 1992, 7:184-190.

55. Szoltys M, Slomczynska M: Changes in distribution of androgen receptor during maturation of rat ovarian follicles. Exp Clin Endocrinol Diabetes 2000, 108:228-234.

56. Cardenas H, Herrich JR, Pope WF: Increased ovulation rate in gilts treated with dihydrotestosterone. Reproduction 2002. 1 23:527-533.

57. Gill A, Jamnongit M, Hammes SR: Androgens promote maturation and signalling in mouse oocytes independent of transcription: a release of inhibition model for mammalian oocyte meiosis. Mol Endocrinol 2004, 18:97-104.

58. Weil S, Vendola K, Zhou J, Adesanya OO, Wang J, Okafor J, Bondy $\mathrm{CA}$ : Androgen receptor gene expression in the primate ovary: cellular localization, regulation, and functional correlations. J Clin Endocrinol Metab 1998, 83:2479-2485.

59. Hillier SG, Tetsuka M, Fraser HM: Location and developmental regulation of androgen receptor in primate ovary. Hum Reprod 1997, I 2:107-III.

60. Tetsuka M, Hillier SG: Androgen receptor gene expression in rat granulosa cells: the role of follicle-stimulating hormone and steroid hormones. Endocrinology 1996, 137:4392-4397.

61. Slomczynska M, Duda M, Slzak K: The expression of androgen receptor, cytochrome $\mathrm{P450}$ aromatase and $\mathrm{FSH}$ receptor mRNA in the porcine ovary. Folia Histochem Cytobiol 200I, 39:9-13.

62. Hampton JH, Manikkam M, Lubahn DB, Smith MF, Garverick HA: Androgen receptor mRNA expression in the bovine ovary. Domest Anim Endocrinol 2004, 27:8I-88.

63. Steckler T, Wang J, Bartol FF, Roy SK, Padmanabhan V: Fetal programming: prenatal testosterone treatment causes intrauterine growth retardation, reduces ovarian reserve and increases ovarian follicular recruitment. Endocrinology 2005:3185-3193.

64. Abbott DH, Dumesic DA, Eisner JW, Kemnitz JW, Goy RW: The prenatally androgenised female rhesus monkey as a model for polycystic ovarian syndrome. In Androgen excess disorders in women Edited by: Azziz R, Nestler JE, Dewailly D. Philadelphia, Lippencott-Raven Press; 1997:369-382.

65. Abbott DH, Eisner JW, Colman RJ, Kemnitz JW, Dumesic DA: Prenatal androgen excess programs for PCOS in female rhesus monkeys. In Polycystic ovarian syndrome Edited by: Change RJ, Dunaif A. Hiendel J. New York, Marcel Dekker Inc; 2002:II9-133.

66. Abbott DH, Barnett DK, Bruns CM, Dumesic DA: Androgen excess fetal programming of female reproduction: a developmental aetiology for polycystic ovary syndrome? Hum Reprod Update 2005, I I:357-374.

67. Wang H, Andoh K, Hagiwara H, Xiaowei L, Kikuchi N, Abe Y, Yamada $\mathrm{K}$, Fatima R, Mizunuma $\mathrm{H}$ : Effect of adrenal and ovarian androgens on type 4 follicles unresponsive to $\mathrm{FSH}$ in immature mice. Endocrinology 200I, 142:4930-4936.

68. Murray AA, Gosden RG, Allison V, Spears N: Effect of androgens on the devlopment of mouse follicles growing in vitro. J Reprod Fert 1998, I I 3:27-33.
69. Hickey TE, Marrocco DL, Amato F, Ritter LJ, Norman RJ, Gilchrist RB, Armstrong DT: Androgens augment the mitogenic effects of oocyte-secreted factors and growth differentiation factor 9 on porcine granulosa cells. Biol Reprod 2005, 73:825-832.

70. Vendola KA, Zhou J, Adesanya OO, Weil SJ, Bondy CA: Androgens stimulate early stages of follicular growth in the primate ovary. J Clin Investig 1998, I 0 I:2622-2629.

71. Cardenas H, Pope WF: Administration of testosterone during the follicular phase increased the number of corpora lutea in gilts. J Anim Sci 1994, 72:2930-2935.

72. Cardenas H, Pope WF: Administration of testosterone from day 13 of the oestrous cycle to oestrus increased the number of corpora lutea and conceptus survival in gilts. J Amin Sci I997, 75:202-207.

73. Hillier SG, Tetsuka M: Role of androgens in follicle maturation and atresia. Baillieres Clin Obstet Gynaecol 1997, I I:249-260.

74. Nimrod A: Studies on the synergistic effect of androgen on the stimulation of progestin secretion by FSH in cultured rat granulosa cells: progesterone metabolism of action. Mol Cell Endocrinol 1977, 8:189-199.

75. Hillier SG, Knazek RA, Ross GT: Androgenic stimulation of progesterone production by granulosa cells from preantral ovarian follicles: further in vitro studies using replicate cell cultures. Endocrinology 1977, 100:1539-1549.

76. Hillier SG, De Zwart FA: Evidence that granulosa cell aromatase induction/activation by follicle-stimulating hormone is an androgen receptor-regulated process in-vitro. Endocrinology 1981, I 09: I303-1305.

77. Weil S, Vendola K, Zhou J, Bondy CA: Androgen and follicle-stimulating hormone interactions in primate ovarian follicle development. I Clin Endocrinol Metab 1999, 84:295I-2956.

78. Vendola KA, Zhou J, Wang J, Famuyiwa OA, Bievre M, Bondy CA: Androgens promote oocyte insulin-like growth factor $I$ expression and initiation of follicle development in the primate ovary. Biol Reprod 1999, 61:353-357.

79. Vendola KA, Zhou J, Wang J, Bondy CA: Androgens promote insulin-like growth factor-I, insulin-like growth factor-I receptor gene expression in the primate ovary. Human Reprod 1999, 14:2328-2332.

80. Bagnell CA, Mills TM, Costoff A, Mahesh VB: A model for the study of androgen effects on follicular atresia and ovulation. Biol Reprod 1982, 27:903-9|4.

8I. Conway BA, Mahesh VB, Mills TM: Effect of dihydrotestosterone on the growth and function of ovarian follicles in intact immature females primed with PMSG. J Reprod Fert 1990, 90:267-277.

82. Hillier SG, Ross GT: Effects of exogenous testosterone on ovarian weight, follicular morphology and intraovarian progesterone concentration in oestrogen-primed hypophysectomized immature female rats. Biol Reprod 1979 , 20:26I-268.

83. Nandedkar TD, Munshi SR: Effect of dihydrotestosterone on follicular development, ovulation and reproductive capacity of mice. J Reprod Fert 198I, 62:21-24.

84. Farookhi R: Effects of androgen on induction of gonadotrophin receptors and gonadotrophin-stimulated adenosin 3', 5'. monophosphate production in rat ovarian granulosa cells. Endocrinology 1980, 106:1216-1223.

85. Jia XC, Kessel B, Welsh TH Jr, Hsueh AJW: Androgen inhibition of follicular-stimulating hormone stimulated luteinizing hormone receptor formation in cultured rat granulosa cells. Endocrinology 1985, I I 7: 13-22.

86. Billig H, Furata I, Hsueh AJW: Oestrogens inhibit and androgens enhance ovarian granulosa cell apoptosis. Endocrinology 1993. I33:2204-22|2.

87. Erhmann DA, Barnes RB, Rosenfield RL: Polycystic ovary syndrome as a form of functional ovarian hyperandrogenism due to dysregulation of androgen secretion. Endocrine Rev 1995, 16:322-353.

88. Balen $A$ : The pathophysiology of polycystic ovary syndrome: trying to understand PCOS, its endocrinology. Best Prac \& Res Clin Obstet \& Gynaec 2004, I 8:685-706.

89. Jonard S, Dewailly D: The follicular excess in polycystic ovaries, due to intraovarian hyperandrogenism, may be the main culprit for the follicular arrest. Hum Reprod Update 2004, 10:107-117. 
90. Abbott DH, Dumesic DA, Franks S: Developmental origin of polycystic ovary syndrome- a hypothesis. J Endocrinol 2002, 174:I-5.

91. Gilling-Smith C, Willis DS, Beard RW, Franks : Hypersecretion of androstenedione by isolated thecal cells from polycystic ovaries. I Clin Endocrinol Metab 1994, 79: I I 58-I I 65

92. De Leo V, Lanzetta D, D'Antona D, Marca A, Morgante G: Hormonal effects of flutamide in young women with polycystic ovary syndrome. / Clin Endocrinol Metab 1998, 83:99-102.

93. Koloszar S, Szollosi J, Bartfai G: Ovulation induction with adjuvant antiandrogentreatment in Stein-Leventhal syndrome. Orv Hetil 1996, 137:2569-257।.

94. Couzinet B, Thomas G, Thalabard JC, Brailly S, Schaison G: Effects of pure antiandrogen on gonadotrophin secretion in normal women and in polycystic ovarian disease. Fertil Steril 1989, 52:42-50.

95. Henmi H, Endo T, Nagasawa K, Hayashi T, Chida M, Akutagawa N, Iwasaki M, Kitajima Y, Kiya T, Nishikawa A, Manase K, Kudo R: Lysyl oxidase and MMP-2 expression in dehydroepiandrosteroneinduced polycystic ovary in rats. Biol Reprod 200I, 64:157-162.

96. Balen AH, Laven JSE, Tan SL, Dewailly D: Ultrasound assessment of polycystic ovary: international consensus definitions. Hum Reprod Update 2003, 9:505-5/4.

97. Takayama K, Fukaya T, Sasano H, Funayama $Y$, Suzuki T, Takaya R, Wada Y, Yajima A: Immunohistochemical study of steroidogenesis and cell proliferation in polycystic ovarian syndrome. Hum Reprod 1996, II:1387-1392.

98. Mason H: Function of the polycystic ovary. Human Fertil (Camb) 2000, 3:80-85

99. McNatty KP, Makris A, DeGrazia C, Osathanondh R, Ryan KJ: The production of progesterone, androgens, and estrogens by granulosa cells, thecal tissue, and stromal tissue from human ovaries in vitro. J Clin Endocrinol Metab 1979, 49:687-699.

100. McNatty KP, Makris A, Reinhold VN, DeGrazia C, Osathanondh R, Ryan KJ: Metabolism of androstenedione by human ovarian tissues in vitro with particular reference to reductase and aromatase activity. Steroids 1979, 34:429-443.

10I. Maciel GA, Baracat EC, Bend J, Markham SM, Hensinger K, Chang RJ, Erickson GF: Stockpiling of transitional and classic primary follicles in ovaries of women with polycystic ovary syndrome. J Clin Endo Metab 2004, 89:5321-5327.

102. Lyon MF, Glenister PH: Reduced reproductive performance in androgen-resistant $\mathrm{Tfm} / \mathrm{Tfm}$ female mice. Proc $R$ Soc Lond $B$ Biol Sci 1980, 208: I-I2.

103. Hu Y-C, Wang P-H, Yeh S, Wang R-S, Xie C, Xu Q, Zhou X, Chao $H-T$, Tsai $M-Y$, Chang C: Subfertility and defective folliculogenesis in female mice lacking androgen receptor. Pro Natl Acad Sci (USA) 2004, I 0 I: I | 209- I I I 4.

104. Dorrington JH, Moon YS, Armstrong DT: Oestradiol- I $7 \beta$ biosynthesis in cultured granulosa cells from hypophysectomised immature rats: stimulation by follicle-stimulating hormone. Endocrinology 1975, 97:1328-1331.

105. Tetsuka M, Hillier SG: Differential regulation of aromatase and androgen receptor in granulosa cells. J Steroid Biochem Molec Biol 1997, 3-6:233-239.

106. Carson RS, Richards JS, Kahn LE: Functional and morphological differentiation of theca and granulosa cells during pregnancy in the rat: dependence on increased basal luteinising hormone activity. Endocrinology 198I, 109:|433-|44|.

107. Hillier SG: Regulation of follicular oestrogen biosynthesis: a survey of current concepts. J Endo Supp 1981:3P-18P.

108. McNatty KP: Ovarian follicular development from the onset of luteal regression in humans and sheep. In Follicular maturation and ovulation Edited by: Rolland R, van Hall EV, Hillier SG, McNatty KP, Shoemaker J. Amsterdam, Excerpta Medica; 1982:I-18.

109. Green S, Walter P, Kumar V, Krust A, Bornet J-M, Argos P, Chambon $P$ : Human oestrogen receptor cDNA: sequence, expression and homology to v-erb-A. Nature 1986, 320:134-139.

110. Green GL, Gilna P, Waterfield M, Baker A, Hort Y, Shine J: Sequence and expression of human oestrogen receptor complementary DNA. Science 1986, 231 : I I 50- II 54.

III. Kuiper GGJM, Enmark E, Pelto-Huikko M, Nilsson S, Gustafsson J-A: Cloning of a novel estrogen receptor expressed in rat prostate and ovary. Proc Natl Acad Sci 1996, 93:5430-5925.

1 12. Chu S, Fuller PJ: Identification of a splice variant of the rat oestrogen receptor $\beta$ gene. Molec Cell Endocrinol 1997, 132:95-99.
113. Petersen DN, Tkalcevic GT, Koza-Taylor PH, Turi TG, Brown TA: Identification of oestrogen receptor $\beta_{2}$, a functional variant of estrogen receptor $\beta$ expressed in normal rat tissues. Endocrinology 1998, 139: I082-1092.

1 14. Byers M, Kuiper GGJM, Gustafsson J-A, Park-Sarge O-K: Oestrogen receptor- $\beta$ mRNA expression in rat ovary: down-regulation by gonadotropins. Molec Endocrinology 1997, I I:I72- I82.

II5. Drummond AE, Baillie AJ, Findlay JK: Ovarian oestrogen receptor $\alpha$ and $\beta$ mRNA expression: impact of development and oestrogen. Molec Cell Endocrinol 1999, I49:153-I6I.

116. Scobie GA, Macperhson S, Millar MR, Groome NP, Romana PG, Saunders PTK: Human oestrogen receptors: differential expression of ERalpha and beta and the identification of ERbeta variants. Steroids 2002, 67:985-992.

II7. Lu B, Leygue E, Dotzlaw H, Murphy LC, Watson PH: Oestrogen receptor- $\beta$ mRNA variants in human and murine tissues. Mol Cell Endocrinol 1998, 138:199-203.

I 8. Ogawa S, Inoue S, Watanabe T, Orimo A, Hosoi T, Ouchi Y, Muramatsu M: Molecular cloning and characterisation of human oestrogen receptor bcx: a potential inhibitor of oestrogen action in human. Nuc Acids Res 1998, 26:3505-35I2.

119. Moore JT, McKee DD, Slentz-Kesler K, Moore LB, Jones SA, Horne EL, Su JL, Kliewer SA, Lehman JM, Willson TM: Cloning and characterisation of human oestrogen receptor beta isoforms. Biochem Biophys Res Commun 1998, 247:75-78.

120. Sar M, Welsch F: Differential expression of oestrogen receptor- $\beta$ and oestrogen receptor- $\alpha$ in the rat ovary. Endocrinology 1999, 140:963-97|.

121. Saunders PT, Millar MR, Williams K, Macpherson S, Harkiss D, Anderson RA, Orr B, Groome NP, Scobie G, Fraser HM: Differential expression of oestrogen receptor-alpha and beta and androgen receptor in the ovaries of marmosets and humans. Biol Reprod 2000, 63: 1098-1105.

122. Pelletier G, Labrie C, Labrie F: Localization of oestrogen receptor $\alpha$, oestrogen receptor $\beta$ and androgen receptors in the rat reproductive organs. J Endocrinol 2000, 165:359-370.

123. Hegele-Hartung C, Seibel P, Peters O, Kosemund D, Muller G, Hillisch A, Walter A, Kraetzschmar J, Fritzemeier K-H: Impact of isotype-selective oestrogen receptor agonists on ovarian function. Proc Natl Acad Sci (USA) 2004, I0 I:5 I 29-5I 34

124. Hisaw FL: Development of the Graafian follicle and ovulation. Physiol Rev 1947, 27:95-119.

125. Richards JS: Hormonal control of gene expression in the ovary. Endocr Rev 1994, 15:725-751.

126. Drummond $A E$, Findlay JK: The role of oestrogen in folliculogenesis. Molec Cell Endocrinol 1999, I 5 I:57-64.

127. Palter SF, Tavares AB, Hourvitz A, Veldhuis JD, Adashi EY: Are oestrogens of import to primate/human ovarian folliculogenesis? Endocrine Rev 200I, 22:389-424.

128. Britt KL, Findlay JK: Oestrogens actions in the ovary revisited. Endocrinol 2002, 175:269-276.

129. Williams PC: Effect of stilboestrol on the ovaries of hypophysectomized rat. Nature 1940, 145:388-389.

130. Payne RW, Hellbaum AA: The effects of oestrogens on the ovary of the hypophysectomised rat. Endocrinology 1955, 57:193-199.

131. Richards JS: Maturation of ovarian follicles: actions and interactions of pituitary and ovarian hormones on follicular cell differentiation. Physiol Rev 1980, 60:5I-89.

132. Carson RS, Zhang Z, Hutchinson LA, Herrington AC, Findlay JK: Growth factors in ovarian function. I Reprod Fert 1989 , 85:735-746.

133. Bley MA, Saragueta PE, Baranao JL: Concerted stimulation of rat granulosa cell deoxyribonucleic acid synthesis by sex steroids and follicle-stimulating hormone. J Ster Biochem Mol Biol 1997, 62:11-19.

134. Richards JS: Perspective: the ovarian follicle- a perspective in 200I. Endocrinology 200I, I 42:2184-2193

135. Charpentier AH, Bednarek AK, Daniel RL, Hawkins KA, Laflin KJ, Gaddis S, MacLeod MC, Aldaz CM: Effects of oestrogen on global gene expression: identification of novel targets of oestrogen action. Cancer Res 2000, 60:5977-5983.

136. Richards JS, Jonassen JA, Rolfes AI, Kersey K, Reichert LE Jr: Adenosine 3', 5'-monophosphate, LH receptor and progesterone during granulosa cell differentiation: effects of oestradiol and FSH. Endocrinology 1979, 104:765-773. 
137. Richards JS, Rolfes Al: Hormonal regulation of cyclic AMP binding to specific receptor proteins in rat ovarian follicles. J Biol Chem 1980, 225:5481-5489.

138. Richards JS, Sharma SC, Falender AE, Lo YH: Expression of FKHR, FKHRLI and AFX genes in the rodent ovary: evidence for regulation by IGF-I, oestrogen and the gonadotrophins. Mol Endocrinol 2002, 16:580-599.

139. Sharma SC, Clemens JW, Pisarska MD, Richards JS: Expression and function of oestrogen receptor subtypes in granulosa cells: regulation by oestradiol and forskolin. Endocrinology 1999 , I 40:4320-4334.

40. Robker RL, Richards JS: Hormone-induced proliferation and differentiation of granulosa cells: coordinated balance of the cell cycle regulators cyclin D2 and p27 Kip I. Mol Endocrinol 1998, I 2:924-940.

14I. Lubahn DB, Moyer JS, Golding TS, Couse JF, Korach KS, Smithies O: Alteration of reproductive function but not prenatal sexual development after insertional disruption of the mouse oestrogen receptor gene. Proc Natl Acad Sci (USA) 1993, 90: III62-III66

142. Couse JF, Lindzey J, Grandrian K, Gustafsson J-A, Korach KS: Tissue distribution and quantitative analysis of oestrogen receptor$\alpha(E R \alpha)$ and oestrogen receptor- $\beta(E R \beta)$ messenger ribonucleic acid in the wildtype and ER $\alpha$-knockout mouse. Endocrinology 1997, I38:4613-4621.

143. Couse JF, Bunch DO, Lindzey J, Schomberg DW, Korach KS: Prevention of the polycystic ovarian phenotype and characterisation of ovulatory capacity in the oestrogen receptor- $\alpha$ knockout mouse. Endocrinology 1999, |40:5855-5865.

I44. Couse JF, Korach KS: Oestrogen receptor null mice: what have we learned and where will they lead us? Endocrine Rev 1999, 20:358-4I7.

145. Schomberg DW, Couse JF, Mukherjee A, Lubahn DB, Sar M, Mayo $\mathrm{KE}$, Korach KS: Targeted disruption of the oestrogen receptor-alpha gene in female mice: characterisation of ovarian responses and phenotype in the adult. Endocrinology 1999 , | 40:2733-44.

146. Rosenfeld CS, Murray AA, Simmer G, Hufford MG, Smith MF, Spears $N$, Lubahn DB: Gonadotrophin induction of ovulation an corpus luteum formation in young oestrogen receptor- $\alpha$ knockout mice. Biol Reprod 2000, 62:599-605.

147. Krege JH, Hodgin JB, Couse JF, Enmark E, Warne M, Mahler JF, Sar M, Korach KS, Gustafsson J-A, Smithies O: Generation and reproductive phenotypes of mice lacking oestrogen receptor $\beta$. Proc Natl Acad Sci (USA) 1998, 95: I 5677-I 5682

148. Cheng G, Weihua Z, Makinen S, Makela S, Saji S, Warner M, Gustaffsson J-A, Hovatta $O$ : $A$ role for the androgen receptor in follicular atresia of oestrogen receptor beta knockout mouse ovary. Biol Reprod 2002, 66:77-84.

149. Emmen JMA, Couse JF, Elmore SA, Yates MM, Kissling GE, Korach KS: In vitro growth and ovulation of follicles from ovaries of oestrogen receptor (ER) $\alpha$ and ER $\beta$ null mice indicate a role for ER $\beta$ in follicular maturation. Endocrinology 2005, I46:2817-2826.

I50. Couse JH, Yates MM, Deroo BJ, Korach KS: Oestrogen receptor$\beta$ is critical to granulosa cell differentiation and the ovulatory response to gonadotrophins. Endocrinology 2005, 146:3247-3262.

15I. Couse JF, Curtis Hewitt A, Bunch DO, Sar M, Walker VR, Davis BJ, Korach KS: Postnatal sex reversal of the ovaries in mice lacking oestrogen receptors $\alpha$ and $\beta$. Science 1999, 286:2328-2331.

152. Dupont S, Krust A, Gansmuller A, Dierich A, Chambon P, Mark M: Effect of single and compound knockouts of oestrogen receptors $\alpha(E R \alpha)$ and $\beta(E R \beta)$ on mouse reproductive phenotypes. Development 2000, I 27:4277-4291.

153. Wu TC, Wang L, Wan YJ: Expression of oestrogen receptor gene in mouse oocyte and during embryogenesis. Mole Reprod Dev 1992, 33:407-4I2

154. Wu TC, Wang L, Wan YJ: Detection of oestrogen receptor messenger ribonucleic acid in human oocytes and cumulusoocyte complexes using reverse transcriptase-polymerase chain reaction. Fert Steril 1993, 59:54-59.

155. Hou Q, Gorski J: Oestrogen receptor and progesterone receptor genes are expressed differentially in mouse embryos during preimplantation development. Proc Natl Acad Sci (USA) 1993, 90:9460-9464

156. Fisher CR, Graves KH, Parlow AF, Simpson ER: Characterization of mice deficient in aromatase (ArKO) because of targeted disruption of the cypl9 gene. Proc Natl Acad Sci (USA) 1998, 95:6965-6970.

I57. Findlay JK: Peripheral and local regulators of folliculogenesis. Reprod Fert Dev 1994, 6:127-139.

I58. Hillier SG: The Parkes lecture: controlled ovarian stimulation in women. J Reprod Fert 2000, I 20:20I-2I0.

159. Britt KL, Drummond AE, Cox AV, Dyson M, Wreford NG, Jones MEE, Simpson ER, Findlay JK: An age-related ovarian phenotype in mice with targeted disruption of the Cyp 19 (aromatase) gene. Endocrinology 2000, 141:26 |4-2623.

160. Britt K, Kerr J, O'Donnell L, Jones M, Drummond A, Findlay J, Simpson E: Defining the roles of sex steroid hormones in the control of differentiation in somatic cells of mammalian gonads. Proc USA Endocr Soc 200I. Abstract OR39-2

16I. Britt KL, Drummond AE, Dyson M, Wreford NG, Jones MEE, Simpson ER, Findlay JK: The ovarian phenotype of the aromatase knockout mouse (ArKO). J Steroid Biochem and Molec Biol 200I, 79: $|8|-\mid 85$

162. Britt KL, Saunders PK, McPherson SJ, Misso ML, Simpson ER, Findlay JK: Oestrogens actions on follicle formation and early follicle development. Biol Reprod 2004, 7 I:I71 2-I723.

163. Britt KL, Stanton PG, Misso M, Simpson ER, Findlay JK: The effects of oestrogen on the expression of genes underlying the differentiation of somatic cells in the murine gonad. Endocrinology 2004, I 45:3950-3960.

164. Toda K, Takeda K, Okada T, Akira S, Saibara T, Kaname T, Yamamura $\mathrm{K}$, Onishi S, Shizuta Y: Targeted disruption of the aromatase P450 gene (Cyp 19) in mice and their ovarian and uterine responses to I 7beta-oestradiol. I Endocrinol 200 I, I 70:99-I I I.

165. Hawkins MB, Thornton JW, Crews D, Skipper JK, Dotte A, Thomas $P$ : Identification of a third distinct oestrogen receptor and reclassification of estrogen receptors in teleosts. Proc Nat Acad Sci (USA) 2000, 97:1075 I-10756.

166. Guigon C], Coudouel N, Mazaud-Guittot, Forest MG, Magre S: Follicular cells acquire Sertoli cell characteristics after oocyte loss. Endocrinology 2005, 146:2992-3004.

167. Otsuka F, Moore RK, Wang X, Sharma S, Miyoshi T, Shimasaki S: Essential role of the oocyte in estrogen amplification of follicle-stimulating hormone signalling in granulosa cells. Endocrinology 2005, 146:3362-3367.

Publish with Biomed Central and every scientist can read your work free of charge

"BioMed Central will be the most significant development for disseminating the results of biomedical research in our lifetime. "

Sir Paul Nurse, Cancer Research UK

Your research papers will be:

- available free of charge to the entire biomedical community

- peer reviewed and published immediately upon acceptance

- cited in PubMed and archived on PubMed Central

- yours - you keep the copyright 